\title{
A charge como agente transformador da realidade: uma análise de sentido do humor gráfico de Henfil no livro “Diretas Já!”
}

\author{
MARCIO ACSELRAD \\ ILO AGUIAR REGINALDO ALEXANDRE
}

Resumo

Henfil foi um dos mais importantes cartunistas do Brasil.

Sua vasta obra marcou o período em que a ditadura militar esteve no poder. O presente trabalho procura depreender a ideologia que orientava as suas charges. Para tanto realizamos um breve histórico do humor político e da charge do autor. Demonstramos como o riso crítico pode iniciar a derrocada de uma instituição e potencializar a criação de uma nova. A metodologia adotada para examinar a ideologia das charges de Henfil foi a semiótica de Greimas.

Palavras-chave:

Henfil, charge, humor 


\title{
Comic strip as a reality transforming agent: an analysis of Henfil's graphic humor in the book "Diretas já!"
}

\author{
MARCIO ACSELRAD \\ ILO AGUIAR REGINALDO ALEXANDRE
}

\begin{abstract}
Henfil was one of the most important cartoonists of Brazil. His vast body of work marked the period when the military dictatorship was in power. The present paper intends to infer the ideology that guided his drawings. Bearing this in mind, we conducted a brief history of Henfil's political humor. We demonstrate how laughter can help initiate the fall of a political institution and be the creator of a new one. The

Keywords: methodology we adopted to examine the ideology of his cartoons was the semiotics of Greimas.
\end{abstract}




\begin{abstract}
Acho que meu trabalho tem um fim. A época do humor pelo humor já passou. Hoje o humor é jornalístico, tem de ser engajado, de ser quente. A fase da comunicação pura e simples acabou. O humor agora é de identificação. $\mathrm{O}$ meu objetivo é a identificação. Procuro dar um recado através do humor. Humor pelo humor é sotifiscação, é frescura. E nesta eu não tou: meu negócio é pé na cara.
\end{abstract}

Henfil

\title{
O martelo
}

Tornar compreensível aquilo que nos é desconhecido é uma das necessidades básicas do ser humano. $\mathrm{O}$ desconhecido nos leva ao perigo, à angustia e à inquietude. Qualquer explicação é melhor do que nenhuma, mesmo que esta seja precária e simplória. Qualquer esclarecimento que sirva para elucidar uma questão é preferível a uma nova explicação. Para se restabelecer a inocência do vir-a-ser é necessário desacreditar nos ídolos: não todo e qualquer ídolo, mas aqueles que não atendam mais às necessidades das pessoas. Aqui os ídolos ganham uma dimensão similar à das instituições reificadas, uma vez que não exercem a funcionalidade que lhes foi atribuída, embora continuem a ter certa credibilidade em parcelas da população. Como retirar as pessoas desse estado de letargia? O filósofo Nietzsche sugere recorrer ao martelo: "Fazer perguntas com o martelo e talvez ouvir como resposta, aquele célebre som oco que vem de vísceras infladas" (NIETZSCHE, 2006, p. 7). Ídolos muito acreditados, mas ocos.

O martelo seria o símbolo ao mesmo tempo de crítica e criação. Ao ser utilizado, ele aponta as falhas que estão presentes na sociedade e, dessa forma, cria a possibilidade de mudar aquela realidade. Esse martelo é o riso. Um riso irônico, de certo modo pessimista e intelectualizado. Um riso que destrói: "Não é com 
cólera, mas com o riso que se mata" (NIETZSCHE, 1994, p. 259). Mas igualmente um riso alegre, esperançoso em criar o novo porque a vontade pessimista não teme negar-se a si mesma, uma vez que se nega com alegria (NIETZSCHE, 2000). Nietzsche acredita tanto no poder transformador do riso, que o coloca acima do bem e do mal:

Esta coroa do risonho, esta coroa de rosas, eu mesmo a cingi, eu próprio canonizei o meu riso. Ainda não encontrei ninguém capaz de fazer outro tanto (...) Aprendei, pois, a rir por cima de vós (...) Esta coroa do risonho, esta coroa de rosas, lanço-vo-la eu, meus irmãos! Canoniza o riso; aprendei, pois, a rir, homens superiores. (NIETZSCHE, 1994, p. 246)

\section{O traço de Henfil}

O mineiro Henrique de Souza Filho, o Henfil, publicou sua primeira charge em 1964, no mesmo ano em que era deflagrado o golpe militar que derrubaria o Presidente João Gullar, na Revista Alterosa. Em 25 de Julho do mesmo ano foi veiculada a primeira história dos Fradinhos, que viriam a ser duas de suas personagens mais famosas. Meses depois a revista foi fechada pela ditadura. A partir de então Henfil não parou mais de produzir. Em 1965 passou a colaborar com o jornal Diário de Minas, onde fazia caricatura política. Em 1967, é convidado pelo filho do teatrólogo Nelson Rodrigues, Jofre Rodrigues, para mudar-se para o Rio de Janeiro e desenhar no popular Jornal dos Sports. Passa então a contribuir também para as revistas Realidade, Visão, Placar e O Cruzeiro.

Em dezembro de 1968 o general-presidente Costa e Silva decretou o Ato Institucional no 5 . Era o golpe dentro do golpe. "Na prática, o ato concentrava nas mãos de Costa e Silva uma quantidade monumental de poder, tornando-o um ditador no sentido pleno da palavra" (BUENO, 2003, p. 347). Nesse ambiente hostil e repressor, em 26 de junho de 1969, foi lançado o jornal O Pasquim. Henfil passa a fazer parte da equipe já na segunda edição. Em pouco tempo era conhecido nacionalmente e seus desenhos eram tidos como os mais politizados e virulentos do periódico. Afirmava que "a chave para você fazer humor engajado é você estar engajado. Não há chance de você ficar na sua casa vendo os engajamentos lá fora e conseguir fazer algo" (SOUZA, 1984, p. 40).

Henfil politizou a charge esportiva, criando personagens que representavam a realidade social dos torcedores cariocas através 
da luta de classes: de um lado, a elite burguesa caracterizada pelo Pó de Arroz (Fluminense) e o Cri-Cri (Botafogo); do outro, os populares Urubu (Flamengo) e Bacalhau (Vasco). Com Zeferino, Bode Orelana e Graúna criticou a miséria nordestina, a luta de guerrilha e os intelectuais. Ubaldo, O Paranóico retratava o medo da volta dos anos de chumbo. O Cabôco Mamadô, administrador do "Cemitério dos mortos-vivos", enterrou famosos que, para ele, eram simpatizantes da ditadura ou simplesmente omissos politicamente. Dentre os sepultados estavam o poeta Carlos Drummond de Andrade, a escritora Clarice Lispector, o jogador de futebol Pelé e a cantora Elis Regina.

De 1977 a 1980, Henfil publicou na revista IstoÉ as Cartas da Mãe, onde humanizou a campanha da anistia através da figura emblemática de seu irmão, o sociólogo Herbert de Sousa, o Betinho (1935-1997), que voltou ao Brasil em 1979. Já em 1980 participou da fundação do Partido dos Trabalhadores. Em 1983 entrevistou Teotônio Vilela (1917-1983), político do Partido do Movimento Democrático Brasileiro que defendia a redemocratização do País. O slogan da redemocratização, da luta por eleições diretas para presidente da República, surgiu nessa entrevista: Diretas Já. Henfil passou então a usar a figura de Teotônio como porta-voz da campanha, embora, anos depois tenha afirmado que ele mesmo havia inventado o slogan da campanha que reuniu, em abril de 1984, mais de um milhão de pessoas no Rio de Janeiro e um milhão e meio em São Paulo. Essas manifestações marcaram simbolicamente o início do fim do regime militar.

Eu do PT. O Teotônio Vilela do PMDB. Fiquei um ano convivendo com ele. Aprendendo uma série de coisas. Eu não concordava com algumas coisas, mas era uma pessoa fascinante. Inclusive, criei Diretas Já para ele. O Teotônio nunca disse Diretas Já. Eu fiz uma entrevista com ele para O Pasquim. Quando terminou a entrevista eu não tinha uma frase de efeito dele. $E$ a gente tem que terminar com uma. Então eu criei essa: "e aí, Teotônio, diretas quando?” “Diretas já!”. (HENFIL, 2009)

Ainda em 1984, Henfil lançou o livro Diretas Já! reunindo crônicas e charges publicadas durante a campanha. Algumas dessas charges serão objeto de nossa análise. Boa parte das crônicas era formada pelas Cartas da Mãe e praticamente não dialogam com as charges em si. Por charges e crônicas serem conteúdos independentes, iremos nos ater apenas às primeiras.

No artigo Retórica da Imagem (1964), o lingüista fran- 
cês Roland Barthes (1915-1980) afirmava que o desenho "obriga imediatamente a certa divisão entre o significante e o insignificante: o desenho não reproduz tudo, frequentemente reproduz muito pouca coisa, sem, porém, deixar de ser uma mensagem forte" (BARTHES, 1998, p. 28).

Os desenhos de Henfil se caracterizam exatamente por essa descrição feita por Barthes. Ao reproduzir uma parcela da realidade, Henfil consegue carregar suas mensagens com alto teor ideológico.

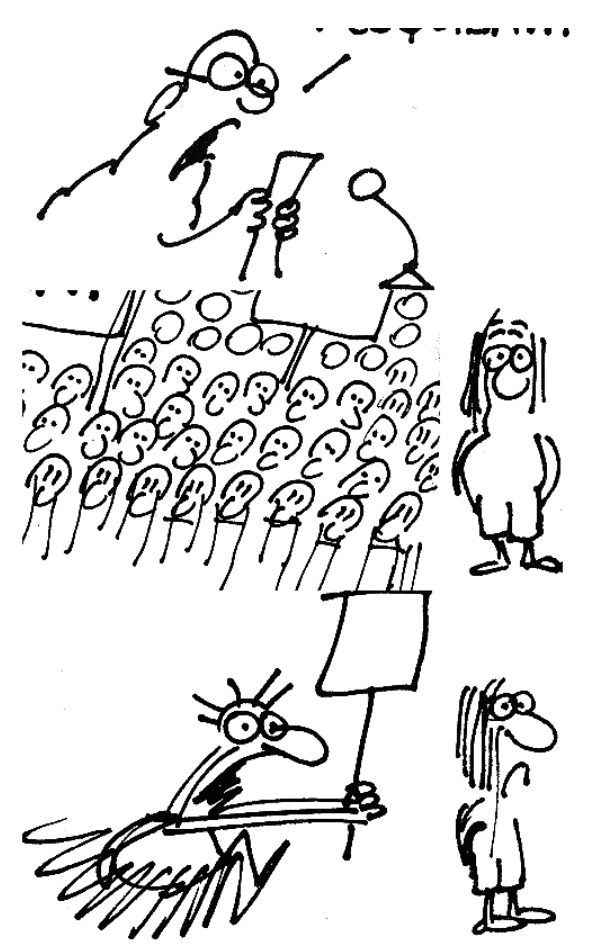

Figura 1

Colagem com detalhes de charges de Henfil: traço.

A colagem realizada na Figura 1 evidencia que os desenhos de Henfil são marcados por poucos e rápidos traços, que conotam movimento. Devido a essa velocidade, muitas vezes as figuras parecem incompletas, dando a impressão de haver certa urgência em finalizar o desenho. Esta suposta falta de acabamento termina por realçar a ideia de movimento. Outra característica é a expressividade que Henfil imprimia a suas personagens. Facilmente conseguimos identificar se aquela personagem está expressando raiva, indiferença ou alegria. Em entrevista concedida ao jornalista Tárik de Souza, Henfil falou sobre o seu estilo. 
Eu comecei tentando imitar todos, os nacionais e estrangeiros. Aí, com a prática e principalmente com a pressa em entregar os trabalhos, fui limpando as mil influências e cheguei ao traço que tenho. O Jaguar define meu desenho como caligráfico, ou seja, eu desenho como escrevo. Se é assim, eu sou cria da minha professora de grupo. O problema é que eu nunca me preocupei seriamente com o desenho. Até hoje uso o mesmo papel do primeiro desenho, ou seja, qualquer um. $\mathrm{O}$ que me mobiliza é o que tenho a dizer, a contar. $\mathrm{O}$ desenho vem atrás da idéia, ele é espelho da idéia. Se eu não tenho uma idéia eu não formo imagens, eu não consigo desenhar nada. Acho que é o mesmo caso do Veríssimo, que não sabe desenhar nada, mas que tem muito a dizer. Aí criou um desenho pessoal feito uma assinatura. E aí você vira uma escola, um caminho (...) Pô, bote uma idéia na cabeça que o desenho vem atrás . (SOUZA, 1984, p. 88)

Outra marca presente nas charges de Henfil é o tom coloquial (Figura 2).

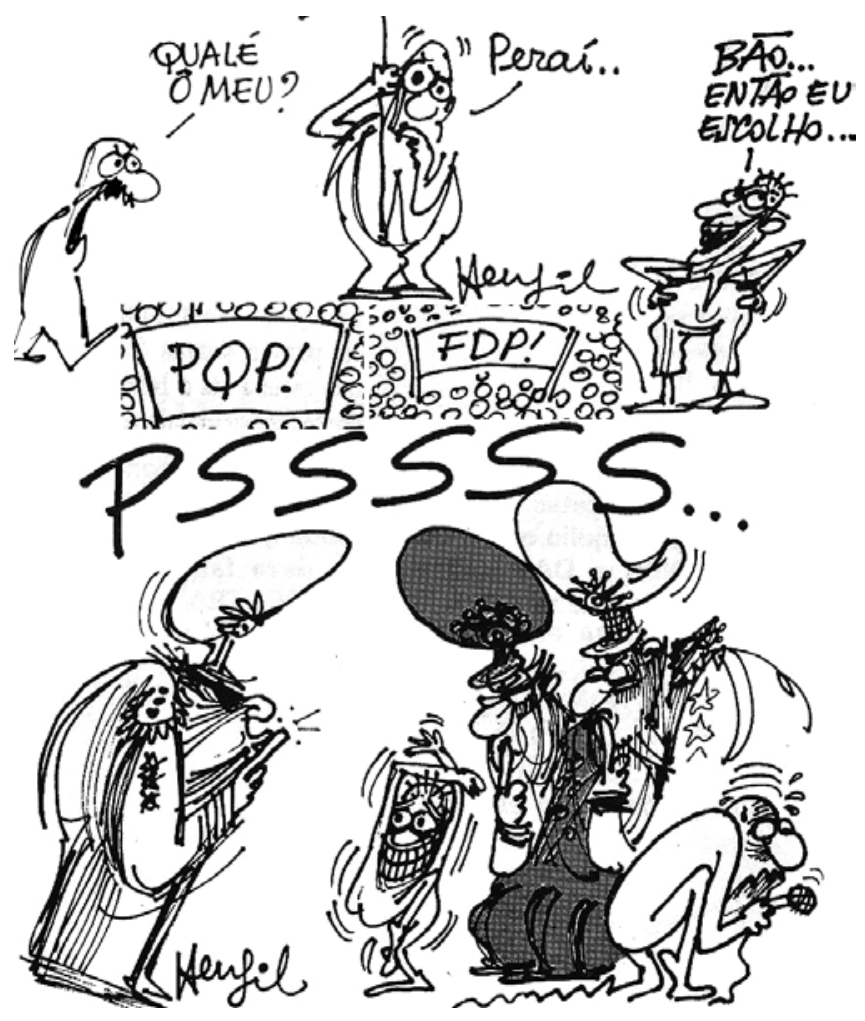


O cartunista inventou expressões que se tornariam célebres como "putz-grila", "top-top", “Cacilda”, etc. Esse caráter informal aproximava o leitor, criando um senso de cumplicidade, uma parceria entre as personagens e os leitores. É importante ainda lembrarmos que o público leitor das charges políticas de Henfil era constituido, em sua maioria, dos membros mais esclarecidos da classe média e da classe alta brasileira.

Essa cumplicidade era fundamental para que a mensagem fosse passada ao leitor. Como muitas personagens são inacabadas, é preciso que o leitor as complete mentalmente. Além disso, se o efeito da ironia não for captado, a charge perde completamente a sua razão de ser. De acordo com a semiótica de Greimas, pode-se afirmar que Henfil é o enunciador do discurso. É ele quem cria figuras e situações (os actantes) para persuadir o enunciatário, neste caso, o leitor.

O enunciador, produtor de conteúdo, cria, através de seus traços, um universo que simula a realidade; gera um espaço, um tempo e personagens definidos, ou seja, estabelece um contexto. É seu papel criar um efeito de verdade para o enunciatário, fazendo com que este acredite em seu discurso. Esse efeito é realizado por meio da manipulação. No caso de Henfil, o recurso normalmente usado para seduzir, o fazer-persuasivo, é a ironia, o riso crítico, de oposição.

O enunciatário, por sua vez, lê aquele conteúdo, que ele sabe ser uma peça humorística, e vai interpretá-lo como verdadeiro ou falso. É esse fazer-interpretativo do leitor que dota a charge de sentido. É esse acordo tácito, essa cumplicidade entre leitor e chargista que torna possível a fruição de uma charge.

\section{As charges do livro Diretas Já!: uma análise semiótica}

Vamos analisar a seguir quatro das vinte e seis charges presentes no livro Diretas Já!, o que representa $15 \%$ do total. Os desenhos foram escolhidos de forma deliberada a fim de retratar as charges com alto teor político. Na primeira charge a ser examinada (Figura 3), a figuração "é caracterizada pela reiteração de traços figurativos, isto é, pela associação entre figuras apresentadas no texto" (LOPES; HERNANDES, 2005, p. 251).

É por meio da figuração que o chargista cria o efeito de realidade. No caso em particular, vendo as vestimentas do homem no canto direito inferior, deduzimos que ele seja um policial, soldado ou militar (recurso semântico). A multidão é representada por milhares de círculos (recurso visual). Na fala 
do militar e nas faixas seguradas pelas pessoas temos a enunciação, a debreagem enunciva (recurso sintático).

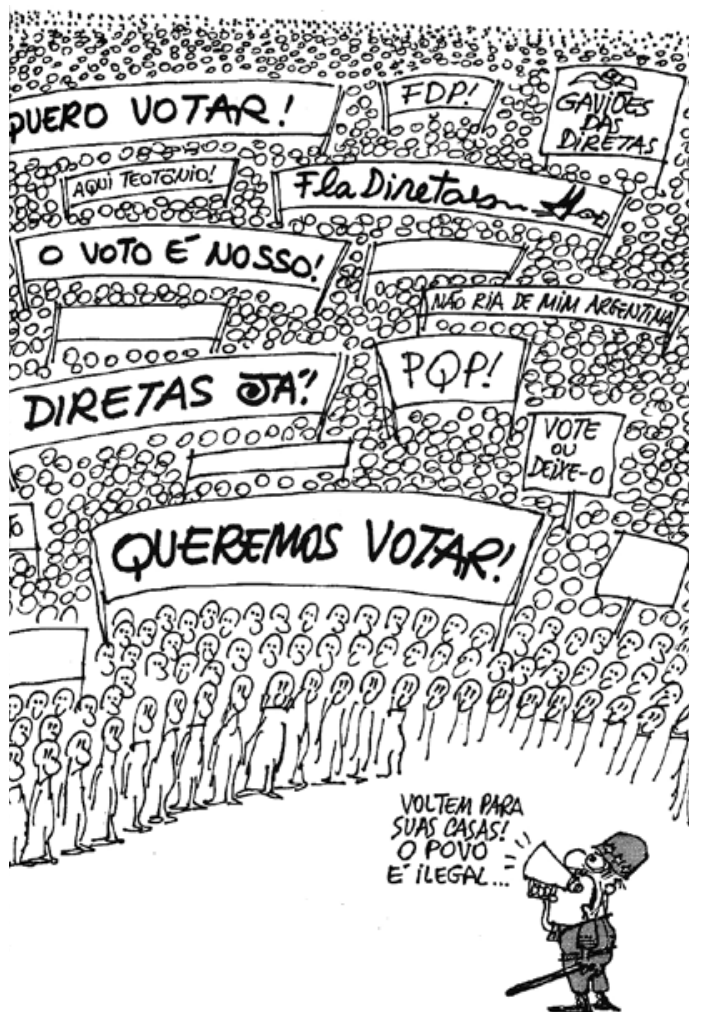

O enunciador (Henfil) possui duas formas de transmitir o seu discurso através da debreagem. Na debreagem enunciativa, o discurso é realizado na primeira pessoa enquanto na debreagem enunciva o enunciador recorre ao discurso na terceira pessoa, procurando dotar o enunciado com um caráter mais objetivo (FIDALGO, 2004).

O caráter mais objetivo que Henfil procurou imprimir às charges desse livro é digno de nota. Ele acreditava estar retratando a realidade, contando um fato tal qual um fotógrafo ou um jornalista, donde o uso da debreagem enunciva.

O fotógrafo vai lá e fotografa; um cara vai lá e se torna cobaia do fato, que é o repórter; e eu desenhava como eu via o fato, então me considerava repórter como qualquer outro, com uma possibilidade de dar uma opinião um pouco mais avançada (SOUZA, 1984, p. 40).
Figura 3

Charge reproduzida do livro Diretas Já! (Henfil, 1984). 
Feita a análise de figuração, todavia, ainda não é possível perceber a temática da charge em sua totalidade. Ela retrata uma manifestação a favor do voto direto. Esse é o nível discursivo. Tratemos agora do nível narrativo. O sujeito-destinatário da charge são os manifestantes, o povo. Ou seja, o próprio leitor (ou o leitor ideal, isto é, aquele que já tenha em germe o desejo de eleições diretas livres). O objeto de desejo do sujeito-destinatário é o voto direto. O sujeito-destinatário aqui é, portanto, o que possui competência, sabe como proceder (saber-fazer), e performance, vai agir de fato (faz-fazer) e transformar o estado do mundo ao seu redor a fim de obter o que deseja, no caso, o voto direto (LOPES; HERNANDES, 2005).

Dito de outra forma, o povo, dentro do qual se encontrava o leitor das charges de Henfil, é o sujeito capaz de mudar a realidade que se apresenta. Ele possuia o conhecimento, a vontade e a capacidade de mudar o processo eleitoral do país. Aqui há uma interseção com a sociologia do conhecimento proposta pelo pensamento de Berger e Luckmann (1985), que tratam da habilidade que o homem possui de transformar a realidade social em que está inserido.

O oponente, que procurava dificultar a missão do sujeito-destinatário, na charge, é representado pelo militar, isto é, o Estado opressor. Henfil, o sujeito-destinador, através da fala do militar ("o povo é ilegal"), utilizou-se da ironia para persuadir e provocar a ação do sujeito-destinatário. A sanção era realizada pelo militar, que impedia que o sujeito-destinatário alcançasse seu objeto de desejo. O militar quebra o contrato estabelecido entre Henfil e o leitor. É nessa quebra de contrato, nessa censura que o militar faz ao povo, que a ironia funciona como crítica do sistema político vigente. A intenção de Henfil ao realizar essa sanção era alfinetar o leitor, perguntando nas entrelinhas: "Esta provocação está sendo feita a vocês. Eles estão dizendo que vocês não existem. E vocês, vão deixar por isso mesmo? Não vão agir?”.

No nível fundamental temos os termos básicos que fundam o sentido elementar da charge. Observamos anteriormente que o objeto de desejo do sujeito é o voto direto. Ora, o voto direto nada mais é do que uma característica da cidadania, uma qualidade daqueles que estão inseridos na vida política de um país. Desse modo, há uma relação de oposição entre dois valores: /inclusão/ versus /exclusão/. A inclusão representa a vontade e o direito de o povo votar no Presidente da República, uma vez que o povo se encontra va excluído do processo. Já a exclusão significa a inclusão de um seleto gru- 
po que possuia a propriedade de escolher o representante do mais alto cargo do Estado, excluindo assim a grande maioria da população. Temos, a partir da interpretação greimasiana, o seguinte quadrado semiótico:

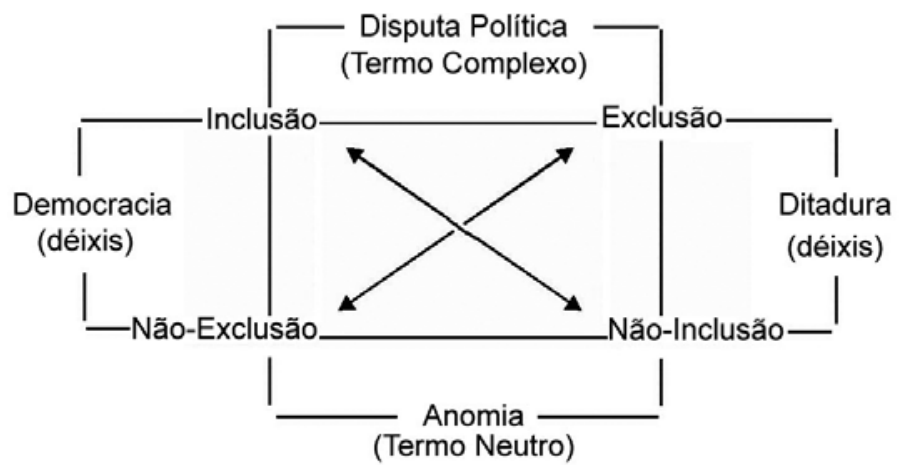

Esquematizando o quadro acima temos:

Os termos /inclusão/ e /exclusão/ constituem o eixo dos contrários. Eles geram um termo hierarquicamente superior (termo complexo), chamado /disputa política/.

Os termos /não-inclusão/ e /não-exclusão/ constituem o eixo dos sub-contrários. Eles também geram um termo superior (termo neutro), chamado /anomia/.

Os termos complementares /não-exclusão/ e /inclusão/geram um termo hierarquicamente superior (dêixis), chamado /democracia/.

Os termos complementares /não-inclusão/ e /exclusão/ também geram um termo superior (dêixis), chamado/ditadura/.

A /não-exclusão/ implica a /inclusão/ política, o que caracteriza uma /democracia/. Da mesma forma, a /não-inclusão/ no processo político pressupõe a /exclusão/, que é qualidade de uma /ditadura/ política. Esses universos (democracia e ditadura) estão contidos dentro de um universo maior, chamado /disputa política/. O que chamamos aqui de /anomia/ é o contrário da /disputa política/, onde os sujeitos simplesmente não querem participar ou não se importam com a vida política do país.

Para concluirmos a sintaxe e a semântica fundamental da charge, resta afirmar que o desenho de Henfil é disfórico, uma vez que o direito ao voto direto é negado. Por mais díspares que sejam as demais charges que iremos analisar, o quadrado semiótico acima descrito se mantêm. O sentido fundamental de todas as charges é representado pela oposição /exclusão/ versus / inclusão/ onde a ironia é a manipulação usada por Henfil como 
martelo para criticar o que está posto e permitir a possibilidade de criar o novo, novos hábitos e novas instituições, no caso, a inclusão do povo no sistema político brasileiro.
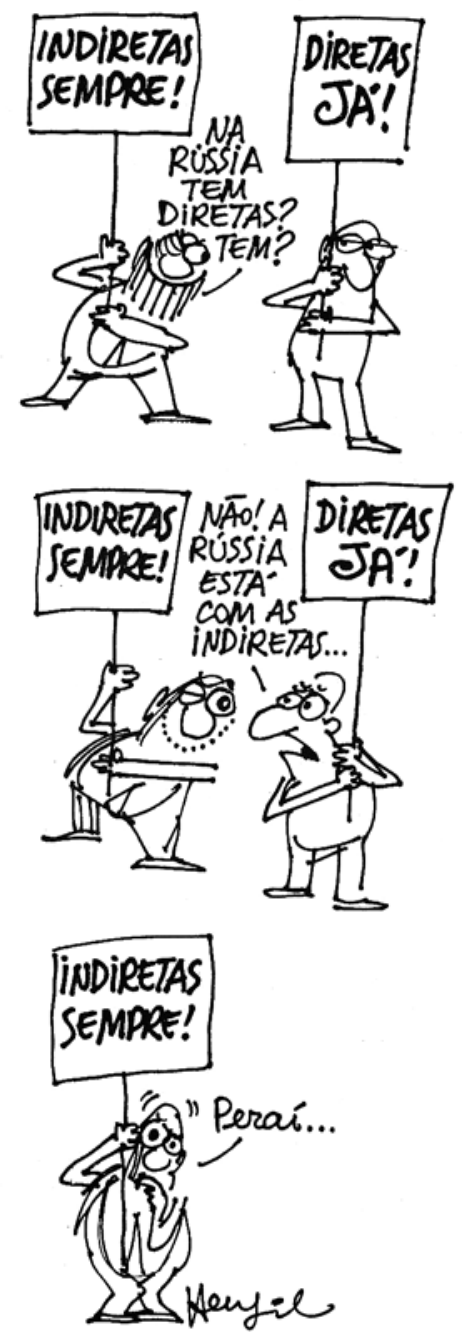

A segunda charge trabalhada encontra-se na Figura 4. Ela se apresenta em um bloco de três quadros. No primeiro quadro duas personagens estão em cena, uma empunhando uma placa com os dizeres "Indiretas Sempre" (que chamaremos de 'A'), a outra com a frase "Diretas Já!" (que chamaremos 
de 'B'). Henfil, o enunciador, desenha 'A' com um olhar e um sorriso malicioso, de quem irá pregar uma peça em 'B'. 'B', por sua vez, olha 'A' de soslaio, cauteloso. No segundo quadro, 'A' permanece com uma expressão cínica, enquanto 'B' arqueia as sobrancelhas para cima, manifestando uma expressão pura, simples, quase ingênua. No terceiro e último quadro temos ' $\mathrm{A}$ ' sozinho, levando a mão à boca, conotando perplexidade e dúvida. Essas são as figuras do texto, que são apreendidas ainda no nível discursivo da narrativa.

A charge não explicita o tempo e o espaço em que se passa a ação, mas pelos dizeres das placas que as personagens seguram, e suas respectivas falas, deduzimos que deve fazer parte do mesmo espaço temporal da charge anterior (Figura 3), um contexto que precedeu a queda do muro de Berlim e o colapso do império soviético. O enunciador e o enunciatário continuam sendo os mesmos, a saber, Henfil e o leitor, respectivamente. 'A' é o destinador da narrativa, que encarrega 'B' de uma missão, responder a pergunta: "Na Rússia tem diretas? Tem?”. 'B', sabedor da resposta (saber-fazer), replica (faz-fazer): “Não! A Rússia está com as indiretas.... Essa não era a resposta que a 'A' esperava ouvir, o que o deixa pensativo. Essas ações desempenhadas pelos sujeitos (actantes) caracterizam o nível narrativo do relato.

O fator humorístico da charge se encontra no fato de a Rússia, que naquele momento histórico fazia parte da União Soviética e era o símbolo do comunismo, eleger os seus representantes políticos através do voto indireto, tal qual o Brasil, que em outras esferas procurava imitar o capitalismo liberal representado pelos Estados Unidos da América.

O que Henfil faz na charge é expor a contradição do governo brasileiro. Se por um lado o governo procura copiar o sistema econômico estadunidense, por outro fecha os olhos para o sistema político deles, baseado no voto direto. Os militares instauraram a ditadura militar por medo que o comunismo chegasse ao Brasil, mas ainda assim não se importam de utilizar o método soviético para eleger os presidentes.

Retomemos o quadrado semiótico. Dizíamos que a oposição de valores existente era entre /inclusão/ versus /exclusão/. Nessa charge a oposição fica mais clara, uma vez que cada uma das personagens defendia um dos valores. 'A', simpatizante da ditadura militar, defendia o voto indireto, que deixava grande parte da população brasileira fora do pleito, caracterizando uma exclusão. 'B', por sua vez, defendia o voto direto, qualidade da democracia e que preza pela inclusão da maioria. 


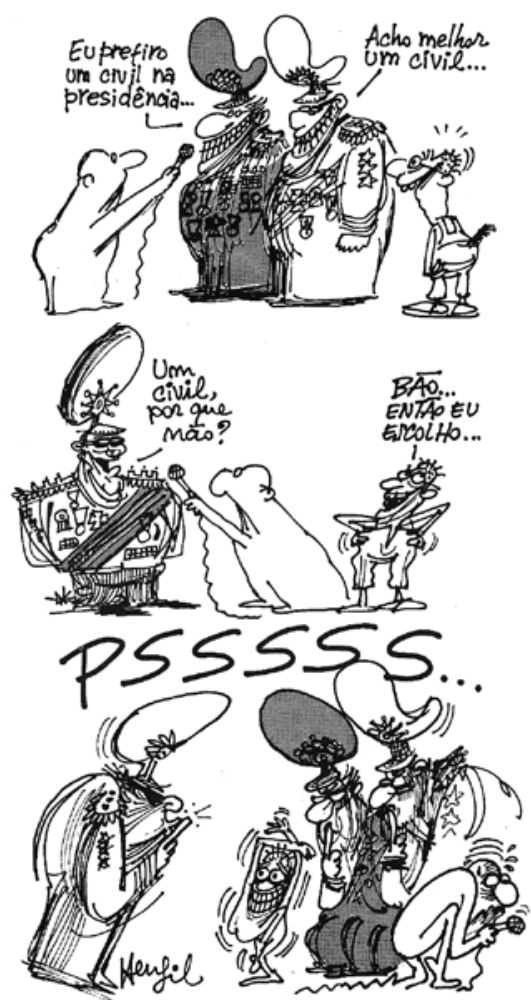
Já! (Henfil, 1984).

A Figura 5 traz a terceira charge que iremos investigar. Assim como a anterior, ela se apresenta em um bloco de três quadros. No primeiro quadro temos quatro personagens. $\mathrm{Na}$ extrema esquerda há um desenho mal acabado, apenas com o número de traços suficiente para depreendermos que é uma pessoa empunhando um microfone, um repórter. No outro extremo, outra personagem rudimentar expressa surpresa. No centro do desenho, ocupando metade do quadro, duas personagens contrastando com as demais. Altos, opulentos e com um sorriso largo, estão com vestimentas militares e muitas insígnias. Ambos afirmam ao repórter preferirem um civil na presidência. No segundo quadro, novamente o repórter direciona o microfone para outro militar enquanto a personagem da direita, que havia expressado surpresa no primeiro quadro, fala: "Bão... Então eu escolho.... No terceiro e último quadro, os militares novamente ocupam boa parte do espaço com a mão na boca, 'pedindo' silêncio à personagem que havia falado no quadro anterior, ação enfatizada pela onoma- 
topéia presente no quadro: "Psssss". Enquanto isso, o repórter sai discretamente de cena. Essas são as informações que as figuras presentes no desenho nos revelam, constituindo o nível discursivo da charge.

Henfil e o leitor permanecem sendo, respectivamente, enunciador e enunciatário da charge. Os militares, ao afirmarem a preferência por um civil na presidência, aparentemente incumbem os cidadãos, representados na charge pela personagem da extrema direita no primeiro e segundo quadro, de escolher o próximo presidente da República. Logo, no nível narrativo, os militares representam o destinador da narrativa enquanto que o cidadão desempenha o papel de destinatário. O cidadão, com a competência necessária para cumprir a tarefa, expressava seu desejo de escolher o próximo presidente (performance), quando era abruptamente interrompido pelos militares. Essa interrupção caracteriza uma sanção por parte dos militares ao cidadão. Significa que o contrato entre destinador e destinatário foi quebrado. O destinatário não entendeu a mensagem que o destinador quis passar. $\mathrm{O}$ cidadão tomou como verdade uma mentira dos militares e por isso foi castigado.

Henfil manipula o discurso procurando obter uma determinada interpretação do leitor sobre a charge. Os militares, cheios de insígnias, são desenhados com preciosismo e estampando um largo sorriso no primeiro quadro. Esse sorriso é lido como cinismo e, ao repreenderem o cidadão, suas falas são lidas como hipocrisia. O leitor provavelmente não irá se identificar com essas personagens falsas, cínicas, hipócritas e dissimuladas.

O olhar de espanto do civil no primeiro quadro conota ingenuidade e simplicidade. O termo coloquial "bão", usado no segundo quadro, cria uma empatia e proximidade com o leitor. Há uma identificação entre o civil e o leitor também pelo fato de o leitor (em princípio) ser um civil e querer o voto direto para presidente da República.

Seguindo o quadrado semiótico temos, de um lado, os militares agindo hipocritamente e defendo a possibilidade de um civil no poder, quando na realidade não querem que isso aconteça. Do outro lado, o civil procura incluir-se, fazer parte do processo eleitoral dizendo que ele quer participar do processo decisório, sendo severamente censurado pelos militares.

A última charge a ser analisada encontra-se na Figura 6. A ação divide-se em seis quadros. No nível discursivo novamente é impossível determinar o tempo e o espaço em que a charge se desenrola. $\mathrm{O}$ que podemos deduzir das figuras presentes no desenho é que à esquerda há uma personagem em cima 
de uma plataforma gritando no megafone (que chamaremos de ' $C$ '). Ầ direita de ' $C$ ', em uma posição inferior, várias cabeças olham com uma expressão de insatisfação para ' $C$ '. A cena se repete nos seis quadros. Enquanto que nos três primeiros ' $C$ ' se exaspera, no quarto quadro há uma hesitação, uma preocupação. No quinto, 'C' aparenta até ter pena da multidão, enquanto que no sexto, expressa um sorriso sem jeito, quase culpado. A multidão, por sua vez, permanece do primeiro ao último quadro com fisionomia de reprovação, de indignação.
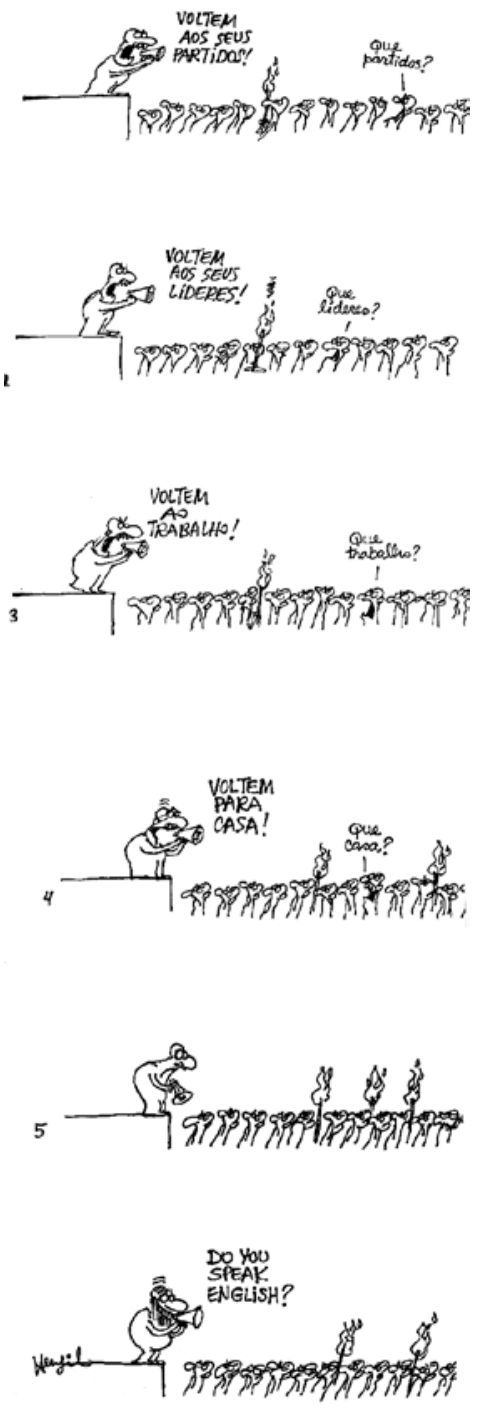
O nível narrativo se apresenta com ' $\mathrm{C}$ ' como destinador da narrativa, encarregando a multidão (destinatária) de executar várias tarefas. 'C' procura persuadir (manipulação) as pessoas a deixarem o local. Essas, todavia, sem possuírem a competência (poder-fazer) para agir (faz-fazer) interrogam à ' $C$ ' como devem proceder. Uma vez que a missão foi falha e o contrato rompido, o enunciador procura, sem sucesso, dar seguimento à narrativa, realizando nova pergunta a multidão, agora em outro idioma: "Do you speak english?".

O fator humorístico do desenho se encontra no fato de, após falhar sucessivamente na tentativa de dispersar a multidão, 'C' tentou usar o artifício de falar em inglês para dissimular o seu fracasso. $\mathrm{O}$ olhar tristonho de ' $\mathrm{C}$ ' no quinto quadro conota uma solidariedade com o povo. Mas essa impressão é rapidamente removida com o sorriso cínico que estampa no sexto e último quadro.

Mais uma vez a oposição/inclusão/ versus /exclusão/ apresenta-se. A multidão não possui partidos políticos, trabalho ou mesmo casa a que possam recorrer. A ignorância de ' $C$ ' sobre o fato demonstra que ele provavelmente possui todos esses predicados. Mais uma vez Henfil desenha o povo reivindicando direitos, enquanto o governo insistia em excluí-los, por exemplo, da possibilidade de se organizem politicamente dentro de partidos.

É pressuposto do enunciador (Henfil) persuadir o enunciatário (leitor) a acreditar em sua ideologia. Pelas charges analisadas fica clara a posição democrática de Henfil. Seu humor irônico, muitas vezes também agressivo, visava desnudar o caráter opressor da ditadura militar, criticando o status quo. Como o martelo de Nietzsche, Henfil procurava destruir a instituição que estava posta para que novos hábitos políticos pudessem ser criados, como uma democracia baseada no voto direto.

A caricatura zombava, escarnecia as instituições. Testava a solidez destas. As instituições são construídas e mantidas diariamente por todos nós, conscientemente ou não. As instituições existem porque elas são convenientes para grande parte da sociedade. Mas quando elas começam a esmorecer, os humoristas estão entre os primeiros a notar, uma vez que eles, principalmente os ironistas, são eternos inconformados, sempre procurando mudar a realidade que os rodeia. Nietzsche acreditava nesse poder transformador do riso. Como um martelo, o riso destruiria as convenções e possibilitaria a criação de algo novo. Por esse caráter fecundo, o filósofo coloca o riso acima do bem e do mal, representando-o como um sim à vida, ao desconhecido e à alegria. 
O cartunista Henfil, acreditamos, corroboraria com a tese do martelo. Buscamos assim, por meio de uma análise semiótica, atingir o sentido fundamental de suas charges e descobrir a oposição motriz do livro Diretas Já!. Vimos que a ideologia que move os desenhos irônicos de Henfil é claramente política. O cartunista possui uma posição definida e a defende em cada charge. Ataca o status quo e a instituição do regime militar, faz troça de suas fraquezas e defende o hábito do voto direito, de forma que todos possam participar do processo eleitoral da escolha do presidente do Brasil, para que assim outra instituição, a democracia participativa, seja novamente estabelecida.

\section{Referências bibliográficas}

ALBERTI, Verena. O riso e o risível: na história do pensamento. Rio de Janeiro: Jorge Zahar Ed., 2002.

BERGER, Peter L.; LUCKMANN, Thomas. A construção social da realidade: de sociologia do conhecimento. Petrópolis: Vozes, 1985.

BRUNO, Fernanda. O riso e o martelo: Alegria, criação e crítica em Nietzsche. Rio de Janeiro: UFRJ, 1994.

BUENO, Eduardo. Brasil: história. São Paulo: Ática, 2003.

FIDALGO, António. Manual de Semiótica. ã: Universidade da Beira do Interior, 2004. Disponível em < http://bocc.ubi. $\mathrm{pt} / \mathrm{pag} /$ fidalgo-antonio-manual-semiotica-2004.html>. Acesso em "16/12/2009".

FONSECA, Joaquim da. Caricatura:a imagem gráfica do humor. Porto Alegre: Artes e Ofícios, 1999.

GEERTZ, Clifford. A interpretação das culturas. Rio de Janeiro: Editora Guanabara, 1989.

GOMES, Regina S. Relações entre linguagens no jornal: fotografia e narrativa verbal. Niteroi: EdUFF, 2008.

HAGUETTE, André. Sociologia:a maneira sociologia de olhar o mundo. Fortaleza. GEO Editora, 1996.

HENFIL. Diretas Já!.Rio de Janeiro: Record, 1984.

HUNGER, Dagmar.; NETO, Samuel, S. A sociologia do conhecimento em Mannheim e Elias: teóricos de investigação social. Rio Claro: UNESP, 2003. Disponível em < ://www. uel.br/grupo-estudo/processoscivilizadores/portugues/ sitesanais/anais7/Trabalhos/xA\%2oSociologia\%2odo\%20 conhecimento\%2oem\%2oMannheim\%2oe\%2oElias\%2o. pdf $>$. Acesso em "16/12/2009".

LOPES, Ivã C.; HERNANDES, Nilton. Semiótica: objetos e 
práticas. São Paulo: Contexto, 2005.

MALTA, José M. M. Henfil: uma educação por linhas tortas. Revista Ensaios - n.1, v.1, ano 1, Rio de Janeiro, 2008. Disponível em <http://www.uff.br/periodicoshumanas/ index.php/ensaios/article/viewArticle/65>. Acesso em "16/12/2009".

MARSICANO, Diego. A semiótica e princípios da construção teatral. Estudos Semióticos, Número 3, São Paulo, 2007. Disponível em < http://www.fflch.usp.br/dl/semiotica/ es>. Acesso em “16/12/2009”.

MINOIS, Georges. História do riso e do escárnio. São Paulo: Editora UNESP, 2003.

NIETZSCHE, Friedrich. A gaia ciência. São Paulo: Companhia das Letras, 2001.

- Humano, demasiado humano: livro para espíritos livres. São Paulo: Companhia das Letras, 2000.

. O nascimento da tragédia, ou helenismo e pessimismo. São Paulo: Companhia das Letras, 1992.

PIRES, Maria da C. F. Cultura e política nos quadrinhos de Henfil. História, São Paulo, v. 25, n. 2, p. 94-114, 2006. Disponível em < ://www.scielo.br/pdf/his/v25n2/o4.pdf $>$. Acesso em “16/12/2009”.

SOUZA, Tárik de. Como se faz humor político. Petrópolis: Vozes, 1984 .

ZECCHETTO, Victorino. Seis semiólogos em busca del lector: Saussure, Peirce, Barthes, Greimas, Eco, Véron. Buenos Aires: La Crujía, 2008.

Recebido em: 09/06/10

Aceito em: 12/10/10

\section{MARCIO ACSELRAD}

macselrad@gmail.com

Doutor em Comunicação pela UFRJ e Professor Titular da UNIFOR

- Universidade de Fortaleza e da FA7, Faculdade Sete de Setembro.

Coordenador do Cineclube Unifor e do LABGRAÇA - Laboratório de

Estudos do Humor e do Riso.

\section{ILO AGUIAR REGINALDO ALEXANDRE}

iloaguiar@gmail.com

Jornalista formado pela Unifor - Universidade de Fortaleza 